\section{Comparison of Micronutrient Sources for Container Rhododendron}

\author{
M ary Ann Rose ${ }^{1}$ and \\ $\mathrm{H}$ ao Wang ${ }^{2}$
}

\begin{abstract}
ADDITIONAL INDEX WORDS. trace elements, diethylenetriaminepentaacetic acid, saturated media extract, soilless media, biosolids compost, nutrition
\end{abstract}

SUmmary. M icronutrient supplements were applied to container rhododendron ( $R$ hododendron $L$, $X$ ' $G$ irards Scarlet' [G irard E vergreen $H$ ybrid G roup]) in three forms: uncoated micronutrient fertilizer; slow-release, N PK-plus-minors fertilizer; and biosolids compost ( $15 \% \mathrm{v} / \mathrm{v})$. Control plants received no supplement. While all micronutrient treatments had significantly higher foliar $\mathrm{M} \mathrm{n}$ or $\mathrm{Cu}$ concentrations than controls 1 year after potting, they did not increase growth (dry weight) or plant quality. At 1, 3, and 12 months after potting, the compost treatment had significantly higher diethylenetriaminepentaacetic acid (DTPA)-extractable levels of $M \mathrm{n}, \mathrm{Fe}$, and $\mathrm{Zn}$ in the medium. 0 nly one micronutrient fertilizer treatment increased extractable micronutrient concentrations ( $\mathrm{Cu}$ ) on all testing dates. Correlations between medium-extractable and foliar micronutrient concentrations were low $\left(r^{2}<0.30\right)$. Vigorous growth in the control treatment suggested that adequate levels of micronutrients were supplied by the pine bark-hardwood bark-peat-sand medium. September concentrations [ppm $\left.\left(\mathrm{mg} \mathrm{L}^{-1}\right)\right]$ as low as 2.0 M n, 17.8 Fe, 0.3 Cu, 4.2 $\mathrm{Zn}$, and $0.9 \mathrm{~B}$ in DTPA extracts produced acceptable growth in rhododendron through the following J une.

\footnotetext{
D epartment of $\mathrm{H}$ orticulture and $\mathrm{Crop}$ Science, The O hio State U niversity, Columbus, OH 43210.

Published as contribution 44-98 of the 0 hio Agricultural Research and Development Center, The O hio State U niversity, Columbus, $\mathrm{OH}$ 43210. The Authors would like to thank The Scotts $\mathrm{C} 0$. for support of this research project. The cost of publishing this paper was defrayed in part by the payment of page charges. U nder postal regulations, this paper therefore must be hereby marked advertisement solely to indicate this fact.

${ }^{1}$ Assistant professor.

${ }^{2}$ Research assistant.
}

$\mathrm{n}$ the late 1960s and 1970s, stand-alone micronutrient fertilizers were developed for use in container media (Whitcomb et al., 1975) and since then have been the most common type of micronutrient supplement used in nursery production. Handrek (1995) found that a single preplant micronutrient charge was as effective as weekly soluble applications in sustaining growth of hebe (H ebe Comm. ex Juss. 'I nspiration') over 12 months. Broschat and D onselman (1985) examined preplant micronutrientsin sulfateor oxideforms or adsorbed to clay carriers. They found that levels of media-extractablemicronutrients decreased during the first month after application but were relatively stable for the following 16 months. $\mathrm{O}$ nly $\mathrm{Fe}$ availability was suboptimal.

Research with biosolids compost (Ticknor et al., 1985) and pine bark ( $N$ iemiera, 1992; W right and $\mathrm{H}$ inesley, 1991) has suggested that micronutrient fertilization may be unnecessary when these materials are used as growing medium components. Even phytotoxic levels of micronutrients may be found in some types of media; for example, hardwood bark may contribute toxic levels of M n (Bunt, 1988; Svenson and Witte, 1992) and compost may have high levels of B (L umis and Johnson, 1982; Rosen et al., 1993). O ther researchers have found micronutrient supply from mediacomponents to be insufficient (pine bark: $\mathrm{H}$ andrek, 1995; Whitcomb et al., 1975) and that micronutrient addition may optimize growth (Wright et al., 1997). In addition to media components, other potential sources of micronutrients to be considered include irrigation water and fertilizer impurities (Bunt, 1988).

While previous research does not consistently support the need for micronutrient fertilizer supplements, manufacturers are producing an increasing number of slow-release fertilizers with minors packages (slow-release + minors products). M icronutrients in these products may be bulkblended with $\mathrm{N}-\mathrm{P}-\mathrm{K}$ prills or may occur within or as part of the prill coating (B. Birrenkott, personal communication). In a preliminary experiment (M.A. R ose, unpublished), micronutrient availability from several of these products and a stand-alone micronutrient fertilizer was examined.
O ne of the slow-release + minors fertilizers and the stand-alone micronutrient fertilizer increased dry weights relative to controls. H owever, significant growth effects were observed on only one of four sampling dates and for one cultivar of rhododendron. Foliar micronutrient concentrationswere not different among treatmentsat any date. $O$ verall, preliminary research provided only weak support for micronutrient fertilization.

O ur primary objective wasto compare medium-extractable and foliar micronutrient concentrations of container plants fertilized with micronutrient sources commonly used in nurseryproduction. Biosolidscompost was incorporated into the medium in one treatment because some nursery producers rely on it to supply micronutrients ( $\mathrm{H}$. H oitink, personal communication). We were particularly interested in the long-term potential for supplying micronutrients to a container crop. A second objective was to determinebenefits, if any, of micronutrient fertilization.

\section{Materials and methods}

Four-inch-square $\left(10-\mathrm{cm}^{2}\right)$ potted liners of rhododendron 'Girards Scarlet' were potted 7 J une 1996 in 1.6-gal (6.1-L) pots containing 3.0 pine bark : 1.0 hardwood bark : 1.0 peat : 0.2 sand (by volume). The medium was amended with gypsum, dolomitic lime, and granular sulfur at 4, 2 , and $1 \mathrm{lb} / \operatorname{yard}^{3}\left(2.4,1.2,0.6 \mathrm{~kg} \cdot \mathrm{m}^{-3}\right)$ respectively. The eight treatments and their corresponding micronutrient sourcesand manufacturersarelisted in T able 1 . In one treatment, the standalone micronutrient fertilizer STEP $\mathrm{H}$ iM ag (ST E P; ScottsC O., M arysville, Ohio) was topdressed at the manufacturer's standard rate of 0.25 oz ( $7 \mathrm{~g}$ ) per pot. In the compost treatment, biosolids compost (Technagro Compost; Kurtz Bros., Cuyahoga $\mathrm{H}$ eights, Ohio) was incorporated at $15 \%$ by volume. Technagro is an invessel composted, belt-dewatered compost with pH 7.5, electrical conductivity $6.9 \mathrm{mmhos} / \mathrm{cm}\left(\mathrm{mS} \mathrm{cm}^{-1}\right)$, containing $1.7 \mathrm{~N}-0.3 \mathrm{~K}-1.2 \mathrm{P}$ and $63 \%$ organic matter (dry weight). In five of the treatments, micronutrient sources werefive different slow-release fertilizers (slow release + minors products). All plants were topdressed with 0.13 oz $(3.8 \mathrm{~g})$ of $\mathrm{N}$ from either 18-6-12 (18N-2.6P-10K) (no micronutrient 
T able 1. Slow-release macronutrient fertilizer source ${ }^{z}$ and analysis, micronutrient fertilizer source, and micronutrient application rate for each experimental treatment.

\begin{tabular}{|c|c|c|c|c|c|c|c|}
\hline \multirow[b]{2}{*}{ Treatment } & \multirow{2}{*}{$\begin{array}{l}\text { Slow-release } \\
\text { N-P-K source }\end{array}$} & \multirow{2}{*}{$\begin{array}{l}\text { Micronutrient } \\
\text { source }\end{array}$} & \multicolumn{5}{|c|}{ Micronutrient (ppm) $)^{y}$} \\
\hline & & & Mn & $\mathbf{F e}$ & $\mathrm{Cu}$ & $\mathbf{Z n}$ & B \\
\hline Control & O smocote $18-6-12$ & No commercial source added & -.- & --- & -.- & -.- & --. \\
\hline Compost $^{\mathrm{w}}$ & O smocote $18-6-12$ & Biosolids compost, $15 \% \mathrm{v} / \mathrm{v}$ & 37.4 & 192.1 & 4.1 & 22.1 & 0.9 \\
\hline STEPv & O smocote $18-6-12$ & $\begin{array}{l}\text { STEP H iM ag: stand-alone micronutrient product } \\
\text { consisting of sulfates \& oxides }\end{array}$ & 34.4 & 91.8 & 5.7 & 11.5 & \\
\hline Customblend ${ }^{u}$ & Customblend $19-5-8$ & $\begin{array}{l}\text { Customblend: sulfates, oxides physically blended with } \\
\text { fertilizer prills }\end{array}$ & 8.2 & 29.5 & 1.6 & 3.3 & \\
\hline Sierra $^{u}$ & Sierra $17-6-10$ & Sierra: sulfates in prill coating & 3.7 & 14.7 & 1.8 & 1.8 & 0.7 \\
\hline O smocote Plus & O smocote Plus 16-8-12 & O smocote Plus: Fe chelate + sulfates inside prill & 2.7 & 19.5 & 2.0 & --- & 0.8 \\
\hline High N Plus & $\mathrm{H}$ igh N Plus 22-4-8 & H i N Plus: sulfates in prill coating & 2.8 & 28.4 & 1.4 & 1.4 & 0.6 \\
\hline N utricote Plus ${ }^{u}$ & Nutricote Plus 18-6-8 & Nutricote Plus: Fe chelate + sulfates inside prill & 2.1 & 6.9 & 1.7 & 0.5 & 0.7 \\
\hline
\end{tabular}

zAll fertilizers manufactured by The Scotts C o., M arysville, O hio except N utricote Plus (Agrivert Inc., Webster, T ex.).

'Weight per volume of potting medium.

${ }^{x}$ All slow-release N-P-K fertilizers were applied at rates of $0.13 \mathrm{oz}(3.8 \mathrm{~g}) \mathrm{N}$ per 1.6-gal (6.1-L) pot.

wM icronutrient application rate calculated by authors from compost elemental analysis.

'The stand-alone micronutrient product STEP H iM ag was applied at manufacturer's suggested standard rate of $0.25 \mathrm{oz}$ ( $7 \mathrm{~g}$ ) per pot.

uM icronutrient application rates calculated from manufacturer's guaranteed analysis.

package) or the slow-release + minors fertilizers (Table 1). All slow-release fertilizers were eight to nine-month release formulas. Different ratios of micronutrients within the products resulted in different micronutrient application rates among treatments (Table 1).

Treatments were arranged in a randomized complete block design in a container nursery with overhead irrigation. Eighteen single-plant replications of each treatment were divided between three blocks. M inolta SPAD 502 Chlorophyll M eter (SPAD; M inolta Camera Co., Ramsey, N.J.) readings of recently matured leaves were taken 29 Aug. 1996. On all medium and foliage sampling occasions, samples were taken from every pot. Samples from each block-treatment combination were mixed together for a composite sample. Recently matured leaves were sampled 9 Sept. 1996 and 1 June 1997. Leaf tissue was dried, ground, and dry-ashed $4 \mathrm{~h}$ at $932^{\circ} \mathrm{F}$ $\left(500^{\circ} \mathrm{C}\right)$; ash was dissolved in $2.4 \mathrm{~N}$ nitric acid before elemental analysis. The growing medium was sampled three times: 14 July 1996, 12 Sept. 1996, and $27 \mathrm{M}$ ay 1997. Except for $\mathrm{NO}_{3}-\mathrm{N}$ analysis, medium sampleswere extracted using the $0.005 \mathrm{M}$ DTPA modification of the saturated medium extract procedure (Warncke, 1988). Distilled water was used as the medium extractant for $\mathrm{NO}_{3}-\mathrm{N}$, which was measured with a nitrate-specific electrode (O rion Research, Cambridge, $M$ ass.). M edium extracts and acid digests were analyzed for $\mathrm{P}, \mathrm{K}$,
$\mathrm{Mn}, \mathrm{Fe}, \mathrm{Cu}, \mathrm{Zn}$, and $\mathrm{B}$ by inductively coupled argon plasmaspectro photometry (Fison Instruments, D earborn, $\mathrm{M}$ ich.) at the O hio State U niversity Research Extension Analytical Laboratory, Wooster.

Plantswereover-wintered between first and second seasonsin a single-layer polyhouse. Shoots from all 144 plants were harvested to measure dry weights one year after potting (1 June 1997). SAS statistical procedures were used for analysis of varianceand mean separation (SAS I nstitute, Cary, N.C). D unnett's two-tailed t test was used to determine statistically significant differences from thecontrol treatment; the protected LSD test was used to compare all means ( $p \leq$ 0.05).

\section{Results and discussion}

Plant appearance, growth reSPONSE, AND MACRONUTRIENT CONCENTRATIONS IN THE MEDIUM. All plants reached salable size by September and flowered thefollowing $\mathrm{M}$ ay. Theplants in the control and compost treatments had excellent color. Plant quality in these treatments was at least asgood as others. Shoot dry weights (Table 2) were not significantly different among treatments, although some color differences were noted. By late August, plants in the Sierra and C ustomblend treatments had lighter green leaves than controls; visual observationswere confirmed by significantly lower SPAD readings(datanot shown). Visual color observations and SPAD readings in other treatments were not different from controls.
$M$ acronutrient concentrations in the medium ( $T$ able 3 ) were measured in July, $\approx 1$ month before the color differences were noted, and also in Sept. Even though plantswere of good quality in most treatments, the $\mathrm{NO}_{3}-\mathrm{N}$ and $K$ concentrations were below the adequate range (Table 3 ) in most and some of the treatments, respectively. $M$ acronutrient concentrations did not suggest why the Sierra and Customblend and treatmentshad poor foliage color by lateAugust. TheSierra treatment actually had higher, but not excessive medium concentrations of $\mathrm{N}, \mathrm{P}$, and $\mathrm{K}$ than controls in July. Perhaps the rate of nutrient release from these fertilizers was insufficient in August. By September, medium N, $P$, and $K$ concentrations in the Sierra and $\mathrm{C}$ ustomblend treatmentswere not different from controls.

\section{Table 2. Effect of micronutrient source on shoot dry weight of rhododendron 'G irards Scarlet' one year after potting.}

\begin{tabular}{lc}
\hline T reatment & Dry wt $\left(\mathbf{g}^{\mathbf{z}}\right)$ \\
\hline Control & $65 \mathrm{a}^{\mathrm{y}}$ \\
Compost & $73 \mathrm{a}$ \\
STEP & $73 \mathrm{a}$ \\
C ustomblend & $69 \mathrm{a}$ \\
Sierra & $75 \mathrm{a}$ \\
O smocote Plus & $66 \mathrm{a}$ \\
$\mathrm{H}$ igh N Plus & $59 \mathrm{a}$ \\
N utricote Plus & $78 \mathrm{a}$ \\
\hline${ }^{2} 10 \mathrm{~g}=0.35$ oz. \\
yM eansfollowed bythesameletter are not significantly \\
different using a protected LSD $(\mathrm{p} \leq 0.05) ; \mathrm{n}=3$.
\end{tabular}


Table 3. Effect of micronutrient source on growing medium macronutrient concentrations of rhododendron 'G irards Scarlet' on two dates during the first growing season.

\begin{tabular}{lccc}
\hline & \multicolumn{3}{c}{ Macronutrient (ppm) } \\
\cline { 2 - 4 } T reatment & $\mathbf{N ~ O}_{3} \mathbf{- N}$ & $\mathbf{P}$ & $\mathbf{K}$ \\
\hline 14 July 1996 & & & \\
Control & $29.1 \mathrm{~b}^{\mathbf{2}}$ & $10.6 \mathrm{bcd}$ & $56.7 \mathrm{~b}$ \\
Compost & $17.1 \mathrm{bc}$ & $23.0 \mathrm{a}$ & $58.4 \mathrm{~b}$ \\
ST EP & $27.3 \mathrm{~b}$ & $11.4 \mathrm{bc}$ & $61.0 \mathrm{~b}$ \\
Customblend & $23.3 \mathrm{bc}$ & $9.2 \mathrm{bcd}$ & $38.3 \mathrm{C}$ \\
Sierra & $51.7 \mathrm{a}$ & $18.3 \mathrm{a}$ & $107.5 \mathrm{a}$ \\
Osmocote Plus & $19.6 \mathrm{bc}$ & $11.9 \mathrm{~b}$ & $65.5 \mathrm{~b}$ \\
H igh N Plus & $12.7 \mathrm{bc}$ & $6.9 \mathrm{bcd}$ & $24.5 \mathrm{~cd}$ \\
Nutricote Plus & $13.9 \mathrm{bc}$ & $5.4 \mathrm{~d}$ & $32.5 \mathrm{~cd}$ \\
12 Sept. 1996 & & & \\
Control & $28.2 \mathrm{a}$ & $14.8 \mathrm{bc}$ & $91.7 \mathrm{ab}$ \\
Compost & $8.8 \mathrm{a}$ & $25.6 \mathrm{a}$ & $51.2 \mathrm{C}$ \\
ST EP & $26.8 \mathrm{a}$ & $18.7 \mathrm{ab}$ & $92.5 \mathrm{ab}$ \\
Customblend & $17.5 \mathrm{a}$ & $12.5 \mathrm{bcd}$ & $57.9 \mathrm{bc}$ \\
Sierra & $12.6 \mathrm{a}$ & $10.1 \mathrm{bcd}$ & $56.8 \mathrm{bc}$ \\
O smocote Plus & $12.1 \mathrm{a}$ & $13.4 \mathrm{bcd}$ & $95.0 \mathrm{a}$ \\
H igh N Plus & $26.9 \mathrm{a}$ & $5.9 \mathrm{~cd}$ & $28.0 \mathrm{c}$ \\
N utricote Plus & $3.3 \mathrm{a}$ & $3.6 \mathrm{~d}$ & $25.6 \mathrm{c}$ \\
Adequate ranges & $40-99$ & $3-5$ & $60-149$ \\
\hline
\end{tabular}

${ }^{\mathrm{z}} \mathrm{M}$ ean separation within columns and dates by protected LSD $(\mathrm{p} \leq 0.05)$.

yAdequate range for concentrations in saturated medium extracts from Warncke and Krauskopf, 1983; $n=3$
DTPA-EXTRACTABLE MICRONUTRIENT LEVELS IN THE GROWING MEDIUM. While the amount of $\mathrm{N}$ applied was constant among treatments, the micronutrient application rates varied due to different ratios within the products (Table 1). Thestand-alone micronutrient fertilizer, STEP, when used at the manufacturer's recommended rate, provided three to four times the quantity of $\mathrm{M} \mathrm{n}, \mathrm{Fe}, \mathrm{Cu}$, and $\mathrm{Z} \mathrm{n}$ supplied by any of the slow release + minors products. H owever, the STEP treatment only increased media-extractable $\mathrm{M} \mathrm{n}$ levelsabove controlson onedate(September 1996, Table 4). The slowrelease +minors products did not raise extractable micronutrient levels above controlsin any consistent pattern, with the exception of the Customblend treatment, which had higher medium $\mathrm{Cu}$ levels on all testing dates. Extractable Fe was not increased by any of the slow-release + minors products.

Thecompost treatment had higher extractable $\mathrm{Mn}, \mathrm{Fe}$, and $\mathrm{Zn}$ than con-

Table 4. E ffect of micronutrient source on growing medium pH and micronutrient concentrations of rhododendron 'G irards Scarlet' on two dates during the first growing season and 1 year after potting.

\begin{tabular}{|c|c|c|c|c|c|c|}
\hline \multirow[b]{2}{*}{ Treatment } & \multicolumn{6}{|c|}{ Micronutrient (ppm) } \\
\hline & pH & $M n$ & $\mathrm{Fe}$ & $\mathrm{Cu}$ & $\mathrm{Zn}$ & B \\
\hline \multicolumn{7}{|l|}{14 July 1996} \\
\hline Control & 4.9 & 5.4 & 29.2 & 0.6 & 5.1 & 0.7 \\
\hline Compost & 5.2 & $18.4^{+}$ & $50.1^{+}$ & 1.5 & $22.6^{+}$ & 0.7 \\
\hline STEP & 4.7 & 8.8 & 37.4 & 1.0 & 9.0 & 0.8 \\
\hline Customblend & 4.7 & 10.9 & 35.6 & $2.9^{+}$ & $15.9^{+}$ & 0.9 \\
\hline Sierra & 5.0 & 7.7 & 29.2 & 1.2 & 4.4 & 1.2 \\
\hline O smocote Plus & 5.5 & 2.9 & 23.8 & 0.9 & 3.7 & 0.9 \\
\hline High N Plus & 5.0 & 6.5 & 33.5 & 0.5 & 5.1 & 0.8 \\
\hline N utricote Plus & 4.9 & 3.5 & 25.9 & 1.0 & 4.2 & 1.0 \\
\hline \multicolumn{7}{|l|}{12 Sept. 1996} \\
\hline Control & 4.5 & 2.1 & 30.2 & 0.3 & 4.2 & 2.3 \\
\hline Compost & $5.6^{+}$ & $14.1^{+}$ & $58.5^{+}$ & 1.6 & $28.4^{+}$ & 1.4 \\
\hline STEP & 4.8 & $7.6^{+}$ & 30.1 & 1.5 & 11.1 & 2.0 \\
\hline Customblend & 4.8 & $7.6^{+}$ & 30.3 & $2.4^{+}$ & 11.5 & 0.9 \\
\hline Sierra & 5.0 & 4.3 & $19.0^{-}$ & 0.7 & 12.3 & 1.1 \\
\hline O smocote Plus & 5.3 & 2.0 & $20.0^{-}$ & 1.4 & 4.2 & 1.9 \\
\hline High N Plus & 4.7 & 2.9 & 28.4 & 0.4 & 5.2 & 0.9 \\
\hline N utricote Plus & 5.2 & 2.3 & $17.8^{-}$ & 1.1 & 4.4 & 0.9 \\
\hline \multicolumn{7}{|l|}{27 M ay 1997} \\
\hline Control & 4.7 & 5.1 & 23.5 & 1.6 & 11.2 & 0.1 \\
\hline Compost & 5.1 & $16.9^{+}$ & $77.2^{+}$ & 1.9 & $26.8^{+}$ & $0.3^{+}$ \\
\hline STEP & 4.5 & 4.3 & 26.3 & 2.3 & 10.8 & 0.1 \\
\hline Customblend & 4.6 & 5.4 & 32.4 & $6.6^{+}$ & 14.9 & 0.1 \\
\hline Sierra & 4.7 & 2.8 & 13.6 & 0.9 & 7.7 & 0.1 \\
\hline O smocote Plus & 4.8 & 2.0 & 19.5 & 2.1 & 5.3 & $0.3^{+}$ \\
\hline High N Plus & 4.8 & 1.5 & 33.0 & 0.8 & 7.1 & 0.1 \\
\hline N utricote Plus & 4.8 & 1.4 & 12.2 & 1.9 & 5.2 & 0.2 \\
\hline Adequate range $^{2}$ & & $5-30$ & $15-40$ & $0.5-1.5$ & $5-30$ & $0.7-2.5$ \\
\hline
\end{tabular}

${ }^{2}$ Adequate range for micronutrient concentrations in $0.005 \mathrm{~m}$ diethylenetriaminepentaacetic acid (DTPA)-saturated medium extracts, from D. Warncke and R. Berghage, personal communication. The + or - symbols to right of treatment means indicate a statistically significant difference from the control treatment using D unnett's two-tailed $t$ test at $p \leq 0.05$. M ean comparisons are made within each column and date; $n=3$. 
Table 5. Micronutrient concentrations in irrigation water and in fresh, unused growing medium components used in the production of rhododendron 'G irards Scarlet'. '

\begin{tabular}{lccccc}
\hline & \multicolumn{5}{c}{ M icronutrient (ppm) } \\
\cline { 2 - 6 } Source & $\mathbf{M n}$ & $\mathbf{F e}$ & $\mathbf{C ~ u}$ & $\mathbf{Z n}$ & $\mathbf{B}$ \\
\hline Irrigation water & 0.03 & 0.03 & 0.06 & 0.30 & 0.06 \\
Biosolids compost & 45.4 & 37.3 & 2.2 & 57.5 & 1.8 \\
Pine bark & 81.4 & 38.7 & 0.2 & 2.2 & 0.6 \\
Composted hardwood bark & 93.1 & 38.7 & 0.3 & 2.7 & 0.5 \\
Peat moss & 0.2 & 21.1 & $<0.1$ & 0.7 & 0.1 \\
\hline
\end{tabular}

${ }^{\mathrm{z}}$ Concentrations in $0.005 \mathrm{~m}$ diethylenetriaminepentaacetic acid (DTPA) extracts of medium components.

trols on all three testing dates, and higher B on $27 \mathrm{M}$ ay 1997. This treatment supplied greater absoluteamounts of these elementsthan other treatments (Table 1). The compost treatment was the only treatment that increased medium $\mathrm{pH}$ (12 Sept. 1996, Table 4), and also increased extractable $P$ (Table 3 ). $\mathrm{H}$ igh levels of $\mathrm{P}$ in media can reduce extractable levels of $\mathrm{Mn}, \mathrm{Fe}$, and $\mathrm{Zn}$ (Broschat and D onselman, 1985); however this was not observed in the compost treatment.

In most treatments, extractable $M n$ and $B$ decreased between the first and last sampling dates, falling below critical ranges developed for the 0.005 M DTPA-saturated medium extract procedure (Table 4). Growing medium concentrations of Fe were relatively stable over the course of theyear. O nly the Sierra and Nutricote Plus treatments fell below the Fe standard on the last sampling date. All treatments had adequate $Z n$ and $C u$ on the last sampling date. Throughout the year, medium micronutrient concentrations may have been maintained by slow release from fertilizer sources, or by cation exchange from growing medium components. Given thestrong evidence of micronutrient availability from the medium components, the latter seems more probable.

The adequate ranges given in Table 4 were developed at M ichigan State U niversity for floral crops, and might need revision for woody ornamentals. By Sept., extractable concentrations $\left[\mathrm{ppm}\left(\mathrm{mg} \cdot \mathrm{L}^{-1}\right)\right]$ were as low as 2.0 M n, 17.8 Fe, 0.3 Cu, 4.2 $\mathrm{Zn}$, and $0.9 \mathrm{~B}$. These concentrationsfell below the standardsfor $\mathrm{Mn}, \mathrm{Cu}$, and $\mathrm{Zn}$, but nonetheless sustained acceptable growth through final harvest the following J une. Although two treatments (Customblend and Sierra) had poor foliage color, availability of micronutrients in the growing medium did not appear to be a factor since other treatments had comparable concentrations but good foliage color.

MicRonUtRIENT CONTRIBUTIONS OF IRRIGATION WATER AND MEDIA COMPONENTS. The irrigation water analysis (Table 5) suggested that water impurities were not a significant source of micronutrients. The $\mathrm{Zn}$ concentration in water was at most $10 \%$ of medium concentrations; $\mathrm{Mn}, \mathrm{Fe}, \mathrm{Cu}$, and $\mathrm{B}$ were proportionately much lower. In contrast, extractable micronutrient concentrations in fresh medium components suggested that these were important sources (Table 5). Biosolids compost ( $\mathrm{T}$ able 5 ) had $\mathrm{Mn}, \mathrm{Fe}, \mathrm{Cu}$, $\mathrm{Zn}$, and $\mathrm{B}$ concentrations within or exceeding the adequate ranges ( $T$ able 4) developed for the 0.005 M DTPAsaturated medium extract procedure. Relative to these standards, peat moss, pine and hardwood bark were also significant sources of $\mathrm{Fe}$, and pine and hardwood bark were sources of $\mathrm{M} \mathrm{n}$.

Foliar NUTRIENT CONCENTRATIONS. Foliar micronutrient concentrations were not different among treatments on the first sampling date (9 Sept. 1996, data not shown). O neyear after potting, all micronutrient treatments had higher foliar $\mathrm{M} \mathrm{n}$ or $\mathrm{Cu}$ levels than controls (Table 6). H owever, elevated foliar $\mathrm{M} \mathrm{n}$ and $\mathrm{Cu}$ did not appear to enhancegrowth of micronutrient treatments since controls were equivalent or superior in quality and size. With the exception of $\mathrm{Cu}$, foliar micronutrient concentrations of the controls fell within or close to adequate ranges (Table 5); this was further evidence that growing medium components supplied adequate amounts of micronutrients. Correlations between foliar micronutrient concentrations and DTPA-extractablemicronutrientswere low (all micronutrients, $r^{2}<0.30$ ).

\section{Conclusions}

The vigorous growth and good color we observed in controls corroborates other research that suggests pine or hardwood bark media may supply sufficient micronutrientsto woody plants (N iemiera, 1992; Svenson and Witte, 1992; Wright and $\mathrm{H}$ inesley, 1991). $\mathrm{N}$ one of the micronutrient-containing fertilizer products increased growth or medium-extractable levels of Fe compared to controls. O nly onemicronutrient fertilizer increased medium-extractablemicronutrients (Customblend- $\mathrm{Cu}$ ) on all three dates. In contrast, the biosolids compost provided higher medium-extractable $\mathrm{Mn}, \mathrm{Fe}$, and $\mathrm{Zn}$ on all dates; this treatment also had significantly higher foliar $\mathrm{M} \mathrm{n}$ concentrations than controls.

Growersshould consider the species, crop duration, growing medium composition, water source, as well as cost when deciding whether to use micronutrient fertilizers. Eliminating micronutrient supplementsfrom astan-

Table 6. Effect of micronutrient source on foliar micronutrient concentrations of rhododendron ' $G$ irards Scarlet' 1 year after potting.

\begin{tabular}{lccccc}
\hline & \multicolumn{5}{c}{ M icronutrient (ppm) } \\
\cline { 2 - 6 } Treatment & Mn & Fe & C u & Z n & B \\
\hline Control & 46.6 & 60.4 & 2.4 & 44.0 & 31.8 \\
Compost & $83.9^{+}$ & 60.6 & 3.0 & 51.8 & 28.3 \\
STEP & $134.4^{+}$ & 64.7 & 2.5 & 58.0 & 30.1 \\
Customblend & $134.6^{+}$ & 58.3 & $3.6^{+}$ & 53.9 & 45.7 \\
Sierra & $85.3^{+}$ & 58.2 & $3.4^{+}$ & 52.5 & 38.2 \\
O smocote Plus & 52.8 & 61.6 & $3.7^{+}$ & 47.9 & 34.8 \\
H igh N Plus & $97.4^{+}$ & 64.4 & $4.0^{+}$ & 54.4 & 40.8 \\
N utricote Plus & 62.0 & 56.2 & $5.1^{+}$ & 46.1 & 47.0 \\
Adequate ranges & $50-200$ & $35-250$ & $6-25$ & $20-200$ & $6-75$
\end{tabular}

"Foliar micronutrient sufficiency ranges from Bailey, D ., T. Bilderback, and D. Bir, Container Substrate and Water $M$ anagement Seminar, 3 J an .1996. The + symbols to the right of treatment means indicate a statistically significan difference from the control treatment using D unnett's two-tailed t test at $p \leq 0.05$. M ean comparisons are made within each column; $n=3$. 
dard cultural program may be advisable only if the primary source of these nutrients wasidentifiable, measurable, and consistent. A final consideration is that this study used a salt-sensitive genus ( $R$ hododendron) and hence a moderaterate of $\mathrm{N}$ fertilization. $\mathrm{O}$ ther studies have suggested that micronutrients might become limiting when rapid growth rates are stimulated by high rates of fertilization (Whitcomb et al., 1975) or lime addition ( $R$. Wright, personal communication).

\section{Literature cited}

Broschat, T.K. and H.M. Donselman. 1985. Extractable M g, Fe, M n, Zn, and Cu from a peat-based container medium amended with various micronutrient fertilizers. J. Amer. Soc. H ort. Sci. 110:196200.

Bunt, A.C. 1988. M edia and mixes for containergrown plants. U nwin $\mathrm{H}$ yman, London.

$\mathrm{H}$ andrek, K.A. 1995. Comparison of preplant and fertigated micronutrients on the growth of $\mathrm{H}$ ebe 'Inspiration'. Commun. Soil Sci. Plant Anal. 26:3063-3081.

Lumis, G.P. and A.G. Johnson. 1982. Boron toxicity and growth suppression of Forsythia and Thuja grown in mixes amended with municipal waste compost. H ortScience 17:821-822.

N iemiera, A.X. 1992. M icronutrient supply from pine bark and micronutrient fertilizers. $\mathrm{H}$ ortScience 27:272.

Rosen, C.J., T.R. H albach, and B.T. Swanson. 1993. H orticultural uses of municipal solid waste composts. H ortT echnology 3:167-173.

Svenson, S.E. and W.T. Witte. 1992. Ca, M g, and micronutrient nutrition and growth of Pelargonium in pine bark amended with composted hardwood bark. J. Environ. H ort. 10:125-129.

Ticknor, R.L., D.D. H emphill, J r., and D .J. Flower. 1985. Growth response of Photinia and Thuja and nutrient concentration in tissues and potting medium as influenced by composted sewage sludge, peat, bark, and sawdust in potting media. J. Environ. H ort. 3:176-180.

Warncke, D. 1988. Recommended test procedures for greenhousegrowth media, p. 34-37. In: Recommended chemical soil test proceduresfor the $\mathrm{N}$ orthCentral region. N orth Central Publ. 221 (revised).

Warncke, D and D. Krauskopf. 1983. Greenhouse growth media: Testing and nutrition guidelines. M ich. State U niv. Ext. Bul. E-1736.

Whitcomb, C.E., A. Storjohann, and W.D. Warde. 1975. M icromax-micronutrientsfor improved plant growth. Proc. Intl. Plant Prop. Soc. 30:462-467.

Wright, R.D. and L.E. H inesley. 1991. Growth of containerized eastern red cedar amended with dolomitic limestone and micronutrients. $\mathrm{H}$ ortScience 26:143-145.

Wright, A.N ., J.K. Fanelli, A.X N iemiera, J.R. H arris, and R.D. Wright. 1997. Amending pine bark with lime and micronutrients affects growth of nine landscapetreespecies. Proc. S. N urseryAssn. 42:7174. 